better position to get profitable returns. Mr. Borlase Matthews mentioned that eight years ago there were 600 British farmers using electricity; the number now is more than 30,000 . He mentioned that electricity was available to every exhibitor in the Show and for the first time they had a telephone exchange in the Show yard.

\section{Practical Difficulties in International Telephony}

IN Europe, telephone operation is mostly in the hands of State administrations, although there are some large private telephone undertakings. To ensure satisfactory international joint working, uniform provisions for the calls are an indispensable necessity. With this end in view, the International Consultative Committee for Telephony, known as the C.C.I.F., has drafted recommendations and working instructions intended for application to international telephone traffic. In the Ericsson Review, No. 1, 1937, Mr. A. Lignell, director of telephones at Stockholm, discusses these recommendations from the point of view of practical operation. He points out that an international call makes use of the subscriber's line, the exchange equipment at both ends and one or more international lines, as well as two or more operators for making the connexions. This type of call is much more difficult to deal with both in respect of time occupied and handling than a local call, and as a rule is of greater importance than a purely local connexion. The C.C.I.F. has therefore recommended that a local call ought to be cut off to allow of an international call, and this is prescribed in its "instructions to operators". At the plenary meeting of the C.C.I.F. in Copenhagen in 1936, there was formulated a question to the following effect, namely, whether international calls should be established with the "least possible delay", instead of connecting them immediately, and so simplifying and cheapening the equipment of local and trunk exchanges. Mr. Lignell is afraid that such simplification would lead to appreciable economic and other disadvantages in international traffic. At the present costs of trunk lines, this seems inevitable. It is to be hoped that the priority over internal traffic which international regulations accord to international traffic may be maintained.

\section{Illuminated Show Cases}

WHEN lamp fittings are used in the normal way, electricians usually assume that the ambient temperature is about $27^{\circ} \mathrm{C}$. and this gives a rise of $23^{\circ} \mathrm{C}$. in the connecting leads before the maximum permissible operating temperature $\left(50^{\circ} \mathrm{C}\right.$.) of the rubber insulation is attained. If the lamp fittings are used in enclosed shop windows or show cases, the assumption about the ambient temperature is no longer valid, as it depends on the aggregate wattage of the lamps in the enclosure. In a technical report of the Electrical Research Association (E.R.A.) published in World Power of April, a very thorough research by H. G. Taylor, W. Lethersich and the late P. D. Morgan has been made to find out the actual heating and to suggest methods of reducing the ambient temperature when excessive. Four methods are considered. A fan can be used to disturb the air, and so provide a uniform temperature throughout the enclosure. Another method is to provide natural ventilation by holes at the top of the case for egress of the hot air and others at the bottom for ingress of the cold air. Forced ventilation may also be used. The last method considered is to use special glass which either transmits the infra-red rays emitted by the lamps, etc., or has a high thermal conductivity and so facilitates the transfer of heat from the inside to the outside of the show case. The first two methods were found to be of considerable value. It was found that if the area of the holes bored in the top and bottom of the show case was about 4 per cent of the area of the top and bottom, the maximum tempera. ture rise was reduced by fifty per cent.

\section{Oil Transport in the Middle East}

So far as is known, the large oil-fields of the Middle East are situated in Iran and Iraq. In Iraq the principal producing field is in the neighbourhood of Kirkup to the east of the Tigris and 145 miles north of Bagdad. In Iran, oil is derived mainly from two large oil-fields. The exploitation of petroleum on a modern commercial scale in these countries is a very recent development which is producing social changes in the ways of the inhabitants, and in the economic sphere it is widening the basis of trade, increasing the revenue and bringing money into the country. In the Year Book of the Cambridge University Engineers' Association for 1936, Colonel H. E. Medlicott describes the engineering difficulties of constructing 1,600 miles of roadway in Iran, sometimes skirting precipitous hillsides. The Anglo-Iranian 0il Company has already raised more than seventy million tons of oil from the two main oil-fields. In Iraq, the Iraq Petroleum Company had under its concession to construct a pipe-line system from Kirkup to the Mediterranean. It was decided that the line should debouch at two points on the Mediterranean, Haifa to the south and Tripoli to the north. The distance along the pipe-line route from Kirkup to the Euphrates is 156 miles, and from there two sections bifurcate, the southern section. going to Haifa and the northern section traversing Syria to Tripoli. The crossings of the Tigris and the Euphrates had to be made by 'Blondins' (overhead cable ways) and steel towers about 140 feet in height had to be erected in concrete to support the massive steel ropeways over the rivers which carried loads of ten tons from one bank and deposited them on the other. The author is strongly of the opinion that the Middle Eastern history of the near future will be a record of steady progress, sociologically, economically and politically.

\section{Mining and Geology in South Australia}

WE have received the annual report of the Director of Mines and Government Geologist of South Australia for 1935 (Adelaide: Government Printer, 1936). After a lengthy list showing that more than a hundred 
plaints were investigated by the wardens, there is a series of short reports concerming mineral deposits, of which the most interesting is probably that "the Government Geologist was appointed to the Geological Advisory Committee assisting the operations of the Anglo-Persian Company's geologists who are making an examination of Australian territory for The Commonwealth Oil Refineries Ltd." This is followed by a report of the chief inspector of mines on the inspection work, whilst the general manager gives a report of the operations of State batteries and cyanide works. The mineral production of 18411935 closes the report, and shows a value of only a little more than 55 million pounds, of which three fifths is derived from copper ore and a quarter derived from iron ore. We have also received the Mining Review (No. 64) for the half-year ending June 30, 1936, of the South Australian Department of Mines. The review records the progress of mining operations in the first half of last year. The largescale operations at Iron Knob and the many small gold mines scattered throughout South Australia are particularly noted.

\section{The Problem of Reality in Physics}

THE April number of Current Science contains a report of a lecture delivered at the Indian Institute of Seience, Bangalore, by Prof. R. Ortvay, of Budapest, on "The Problem of Reality in Physics". Prof. Ortvay outlined the positivistic and realistic attitudes in physical science, the contrast between which he described as analogous to the relation between nominalism and realism in philosophy. To the positivist our only direct data are sensations, which alone constitute physical reality. All other 'existence' is constructed mentally out of sensations, and possesses a lower degree of importance. It follows that it is a senseless question whether anything exists that cannot be observed. This doctrine originated with Mach, and is shared by Bohr, Heisenberg, Dirac, Schrödinger and Philipp Franck. On the other hand, physical realism, the chief representatives of which in physics are Planck, Laue and Sommerfeld, chooses as its fundamental task the construction of a description of the world which is independent of our individuality. In Prof. Ortvay's opinion, positivism and realism are ultimately equally legitimate, just as in a logical system it is to a certain degree arbitrary what is to be considered as belonging to the basis of the system and what as a deduction. Positivism, in the form which was developed under the influence of quantum mechanics, leads to a profound change of our idea of the physical state of a system, but does not destroy the notion of the objectivity of a state, and so is not beyond realistic expression. On the other hand, Prof. Ortvay does not agree with the identification of observability and existence. $\mathrm{He}$ believes that we must maintain that certain things exist which can never be observed.

\section{Research on Radium Therapy}

RADIUM therapy in Great Britain was given a great stimulus with the formation of the Radium Beam
Therapy Research unit towards the end of 1933. A series of papers during the last two years shows valuable contributions on many sides of the subject. Two of these papers have appeared in Nature, one in the Journal of Scientific Instruments upon the properties of a new tungsten-nickel-copper alloy, the remaining seven in the British Journal of Radiology. Most of these papers are contributed by physicists, and deal in an exhaustive way with the physical properties of the radiation used and its intensity variations among the tissues that it penetrates. One paper, entitled "Delivery, Estimation and Control of Tissue Dosage in Radiation Therapy", by C. A. P. Wood and T. A. Green, exhibits in the most happy way how the carefully acquired physical data are being put to the direct service of the clinic. This paper may be said to mark an advance in the development of the use of big radium units in the treatment of eancer. The paper shows the importance of a knowledge of the state of radio-sensitiveness of the tumours being treated and how a best selection of the ports of entry of the radiation can only be made by those having the necessary anatomical knowledge combined with experience of the various modes of spread of cancer.

\section{Indian Science Congress Association: Silver Jubilee}

THE twenty-fifth annual session of the Indian Science Congress Association will be held in Calcutta on January 3-9 under the presidency of the Right Hon. Lord Rutherford. To mark the silver jubilee of the Association, the meeting is to be a joint session with the British Association. About a hundred men of science have been invited from Great Britain, while invitations have also been extended to a number of scientific workers in other countries. The Congress will be divided into the following sections under the presidents named: (1) Mathematics and Physics, Dr. C. W. B. Normand, director-general of observatories, Meteorological Office, Poona 5 ; (2) Chemistry, Prof. S. S. Bhatnagar, director, University Chemical Laboratories, Lahore; (3) Geology, Mr. D. N. Wadia, officiating superintending geologist, Geological Survey of India, 27 Chowringhee, Calcutta; (4) Geography and Geodesy, Dr. A. M. Heron, director, Geological Survey of India, 27 Chowringhee, Calcutta; (5) Botany, Prof. B. Sahni, professor of botany, University of Lucknow ; (6) Zoology, Prof. G. Matthai, professor of zoology, Government College, Lahore; (7) Entomology, Mr. M. Afzal Husain, principal, Punjab Agricultural College, Lyallpur, Punjab ; (8) Anthropology, Dr. B. S. Guha, Zoological Survey of India, Indian Museum, Calcutta; (9) Agriculture, Rao Bahadur T. S. Venkatraman, Imperial sugar-cane expert, Lawley Road, Coimbatore; (10) Medical Research, Sir Upendranath Brahmachari, professor of tropical medicine, Carmichael Medical College, Calcutta, and honorary professor of bio-chemistry, University of Calcutta; (11) Veterinary Research, Sir Arthur Olver, animal husbandry expert, Imperial Council of Agricultural Research, New Delhi ; (12) Physiology, Col. R. N. Chopra, officiating director and 